\title{
SYSTEM MODEL FOR WEB-BASED TEACHER PERFORMANCE ASSESSMENT
}

\author{
Hilyah Magdalena ${ }^{1}$, Umami $^{2}$, Hadi Santoso ${ }^{3}$ \\ ${ }^{1}$ Program Studi Sistem Informasi STMIK Atma Luhur \\ Pangkalpinang - Bangka Belitung, (0717) 433506, e-mail: hilyah@atmaluhur.ac.id \\ ${ }^{2}$ Program Studi Sistem Informasi STMIK Atma Luhur \\ Pangkalpinang - Bangka Belitung, (0717) 433506, e-mail: umamichan723@gmail.com \\ ${ }^{3}$ Program Studi Sistem Informasi STMIK Atma Luhur \\ Pangkalpinang - Bangka Belitung, (0717) 433506, e-mail: hadimkom@gmail.com
}

\section{ARTICLE INFO}

Article history:

Received 14 June 2019

Received in revised form 25 July 2019

Accepted 26 July 2019

Available online 30 July 2019

\begin{abstract}
The performance of teachers in educational institutions needs to have an appreciation and assessment that has a basis. Teacher performance assessment is one of the bases for decision making related to the career of the teacher. To improve the quality and accuracy of performance appraisal, this study designs a web-based teacher performance assessment decision support system. The Decision Support System method used is Analytical Hierarchy Process (AHP), and information system design uses the Object Oriented Analysis and Design (OOAD) method. Respondents in this study were deputy principals, teacher representatives, and committee representatives. The results of the calculation of the respondent questionnaire were carried out with a paired comparison matrix. The results of the combined calculation showed that the first level criteria which were the highest weighted were Social with a weight of $33.4 \%$ and the alternative teacher with the best performance was Vera Asmara with a value of $22.9 \%$.
\end{abstract}

Keywords: Teacher Performance, DSS, AHP.

\section{Pendahuluan}

Sekolah Dasar sebagai salah satu instansi pendidikan pertama di urutan jenjang pendidikan di Indonesia sangat membutuhkan guru - guru yang berkinerja baik. SDN 14 Sungailiat adalah sebuah sekolah dasar yang telah beroperasi sejak tahun 1989. SDN 14 dalam upayanya untuk meningkatkan kualitas, berusaha mendorong guru - guru untuk mempunyai kualifikasi akademik dan non akademik yang berkualitas untuk mendukung pembelajaran. Salah satu upaya meningkatkan kualitas guru adalah dengan menetapkan standar penilaian kinerja. Untuk menjamin standar penilaian kinerja guru, maka seorang guru secara rutin mendapat penilaian kinerja. Penilaian kinerja guru (PKG) dilakukan oleh Kepala Sekolah sebagai pimpinan sekolah. PKG ini bertujuan untuk memonitor kualitas guru secara berkrala. Berdasarkan kebutuhan dan kondisi sekolah saat ini, Kepala Sekolah menyadari bahwa penilaian kinerja guru di SDN 14 Sungailiat mempunyai multi kriteria dan juga multi alternatif. Penilaian kinerja guru mempunyai multi kriteria karena melibatkan faktor pedagogik, kepribadian, sosial, dan profesional. 
Selanjutnya penilaian kinerja guru juga mempunyai multi alternatif karena dalam satu tahun periode penilaian melibatkan beberapa guru. Sistem yang mengandung multi kriteria dan multi alternatif ini yang mendorong penelitian ini menggunakan metode Analytical Hierarchy Process (AHP), dengan metode AHP, semua kriteria dalam sistem penilaian kinerja guru akan disusun secara hirarki dan tingkat kepentingan tiapa kriteria dihitung secara akurat. Berdasarkan kondisi tersebut, maka penelitian ini fokus pada upaya mendesain sistem pendukung keputusan yang berbasis web untuk menilai kinerja guru dengan metode Analytical Hierarchy Process (AHP).

Peran penting dan strategis guru dalam mewujudkan masyarakat Indonesia yang sejahtera tercantum dalam PP No.19 Tahun 2017 tentang guru yang secara jelas menyatakan bahwa Guru adalah pendidik profesional dengan tugas utama mendidik, mengajar, membimbing, mengarahkan, melatih, menilai, dan mengevaluasi peserta didik pada pendidikan anak usia dini, jalur pendidikan formal, pendidikan dasar, dan pendidikan menengah[1]. Definisi serupa juga terdapat pada UU Guru dan Dosen tahun 2005[2]. Untuk menjamin kriteria penilaian kinerja guru mempunyai dasar yang kuat, maka umumnya sekolah menilai kinerja guru dari kompetensi evaluasi pendidikan yang secara garis besar menilai kinerja dari Standar Kompetensi Guru dikembangkan secara utuh dari 4 kompetensi utama, yaitu: (1) kompetensi pedagogik, (2) kepribadian, (3) sosial, dan (4) profesional. Keempat kompetensi tersebut terintegrasi dalam kinerja guru[3]. Setelah mendapat dasar hukum yang kuat terkait dengan perlunya menilai kinera guru, tahap selanjutnya adalah menganalisa beberapa penelitian terdahulu yang serupa. Penelitian yang mengambil tema tentang sistem pendukung keputusan penilaian guru dengan AHP di Yayasan Lentera Insan. Penelitian ini menggunakan 15 kriteria untuk menilai 4 kinerja guru terbaik di yayasan tersebut[5]. Metode AHP juga digunakan untuk menyeleksi guru - guru dengan kinerja terbaik pada SMK BINA PUTRA[6]. Guru - guru di SD LPI AT-TAUFIQ yang berlokasi di Kecamatan Cempaka Putih Kota Administrasi Jakarta Pusat Provinsi DKI Jakarta juga memanfaatkan metode AHP untuk menilai kinerja gurunya[7]

\section{Metode Penelitian Analytical Hierarchy Process}

AHP adalah alat bantu yang mampu mendukung pengambilan keputusan multi kriteria[8]. AHP adalah metode pengambilan kepusan yang diperkenalkan oleh Thomas L. Saaty pada tahun 1972, pada penelitiannya, Saaty menjelaskan bahwa AHP adalah pendekatan pengambilan keputusan multi kriteria yang menyusun banyak kriteria tersebut dalam sebuah hirarki[9]. Thomas L.Saaty dan Luis G. Vargas juga menyimpulkan bahwa AHP dapat dilakukan untuk mendukung pengambilan keputusan di bidang ekonomi, ilmu sosial, dan hal - hal yang berkaitan dengan nilai - nilai kemanusiaan[10]. Menurut Thomas L. Saaty, konsep dasar dari AHP adalah pengolahan data secara matematis dengan urutan dekomposisi, perbandingan berpasangan, dan menyusun sintesa prioritas[11]. Penelitian Thomas L.Saaty yang lain menyimpulkan bahwa proses pengambilan keputusan seharusnya melibatkan banyak faktor yang tidak terukur. Agar faktor tidak terukur ini juga dapat dijadikan kriteria dalam pengambilan keputusan, maka pendekatan AHP dapat digunakan oleh para pengambil keputusan[12]. Persoalan pengambilan keputusan dengan AHP kadang menimbulkan masalah saat proses membutukan beberapa orang pengambil keputusan. Dalam hal ini Ernest Forman dan Kirti Peniwati menyimpulkan bahwa kondisi ini dapat memilih antara mengasumsikan pengambilan keputusan bersama atau sebagai keputusan individu yang terpisah[13]. Untuk mengatasi masala jumlah pengambil keputusan tersebut, pada tahun 2015, Thomas L. Saaty dan Mujgan Sa gir Özdemir menghasikan penelitian yang menyimpulkan bahwa menggabungkan beberapa pengambil keputusan seharusnya tidak dilakukan secara acak. Para pengambil keputusan yang terlibat harus pakar dibidangnya dan mampu mengambil keputusan dengan dilandasi pengetahuan dan pengalaman yang mumpuni[14]. Tahap - tahap penelitian dengan metode pendukung keputusan AHP diuraikan sebagai berikut :

TRANSFORMATIKA Vol. 17, No. 1, July 2019: $67-77$ 


\subsection{Comparative Judgement}

Prinsip ini berarti membuat penilaian tentang kepentingan relatif dua elemen pada suatu tingkat tertentu dalam kaitannya dengan tingkat di atasnya. Penilaian ini merupakan inti dari AHP, karena ia akan berpengaruh terhadap prioritas elemen - elemen. Dalam penyusunan skala kepentingan ini, digunakan acuan seperti pada tabel 1 berikut:

Tabel 1. Skala prioritas dalam AHP

\begin{tabular}{cl}
\hline Nilai Numerik & \multicolumn{1}{c}{ Tingkat Kepentingan (Preference) } \\
\hline 1 & Sama pentingnya (Equal Importance) \\
2 & Sama hingga sedkit lebih penting \\
3 & Sedikit lebih penting \\
4 & Sedikit lebih hingga jelas lebih penting \\
5 & Jelas lebih penting (Materially more Importance) \\
6 & Jelas hingga sangat jelas lebih penting \\
7 & Sangat jelas lebih penting (Significantly more) \\
8 & Sangat jelas hingga mutlak lebih penting \\
9 & Mutlak lebih penting (Absolutely more) \\
\hline
\end{tabular}

\subsection{Synthesis of Priority}

Dari setiap pairwise comparison kemudian dicari eigen vector-nya untuk mendapatkan local priority. Karena matriks pairwise comparison terdapat pada setiap tingkat, maka untuk mendapatkan global priority harus dilakukan sintesa diantara local priority. Prosedur melakukan sintesis berbeda menurut bentuk hirarki. Pengurutan elemen-elemen menurut kepentingan relatif melalui prosedur sintesa dinamakan priority setting.

\subsection{Logical Consistency}

Konsistensi memiliki dua makna. Pertama adalah bahwa objek-objek yang serupa dapat dikelompokkan sesuai dengan keseragaman. Kedua adalah menyangkut tingkat hubungan antara objek-objek yang didasarkan pada kriteria tertentu.

\subsection{Tahap - Tahap Penelitian SPK dengan Metode AHP}

Penelitian ini secara garis besar menggunakan metode Analytical Hierarchy Process (AHP) untuk proses pengambila keputusan. Setelah pola pengambilan keputusan diperoleh maka tahap selanjutnya adalah mendesain sistem berbasis web dengan metode Object Oriented Analysis and Design (OOAD) dengan bahasa Unified Modelling Language (UML). Tahap - tahap mengambil keputusan dengan AHP terdiri dari tiga tahap dasar yaitu, dekomposisi, perbandingan berpasangan, dan menghitung sintesis prioritas. Berdasarkan hal itu, maka gambar 1 menunjukkan tahap penelitian secara keseluruhan. Gambar 1 menampilkan tahap pertama penelitian adalah observasi dengan langsung melihat proses penilaian kinerja guru di SD Negeri 14 Sungailiat, lalu identifikasi masalah berdasarkan kerumitan dan banyaknya komponen dalam proses penilaian kinerja guru dan sekaligus menetapkan tujuan penelitian yaitu meningkatkan efisiensi penilaian kinerja guru dengan sistem pendukung keputusan yang berbasis web. Pengumpulan data dilakukan dengan dua cara yaitu mengumpulkan data awal perusahaan yang berupa kuesioner dan studi pustaka dari hasil penelitian terdahulu yang serupa. Setelah data penelitian lengkap selanjutnya adalah mengolah data dengan metode Analytical Hierarcy Process (AHP). Hasil sistesis pengolahan data menjadi dasar pengambilan kesimpulan tentang kriteria apa saja yang paling berpangaruh dalam sistem pendukung keputusan untuk penilaian kinerja guru dan saran yang berguna untuk pengembangan sistem pendukung keputusan yang berbasis web. 


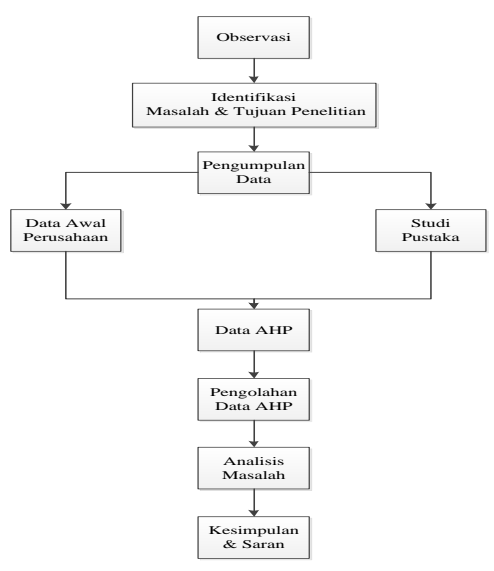

Gambar 1. Tahap - Tahap Penelitian

Khusus untuk detil pengolahan data AHP ditunjukkan pada gambar 2 berikut :

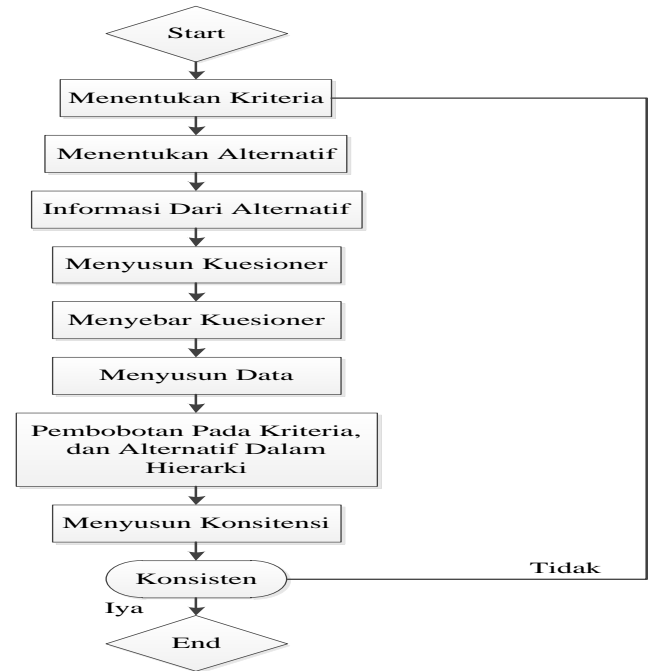

Gambar 2. Tahap Pengolahan Data dengan Metode AHP

Gambar 2 menunjukkan pola pengambilan keputusan berdasarkan metode AHP. Perhitungan Analytical Hierarchy Process (AHP) dimulai dengan melakukan perbandingan berpasangan antar kriteria pada level yang sama. Elmen-elmen pada setiap baris dari matriks persegi merupakan hasil perbandingan berpasangan. Setiap matriks pairwise comparison dicari eigen vektor nya untuk mendapat local priority. Skala perbandingan berpasangan didasarkan pada nilai-nilai fundamental Analitycal Hierarcy Process dengan pembobotan dari 1 untuk sama penting, sampai dengan 9 untuk sama penting sekali.

\section{Hasil dan Pembahasan}

Variabel - variabel penelitian pada penelitian ini terdiri dari kriteria utam dan sub kriterianya seperti yang terlihat pada kerangka hirarki analitik berikut ini,

TRANSFORMATIKA Vol. 17, No. 1, July 2019: $67-77$ 


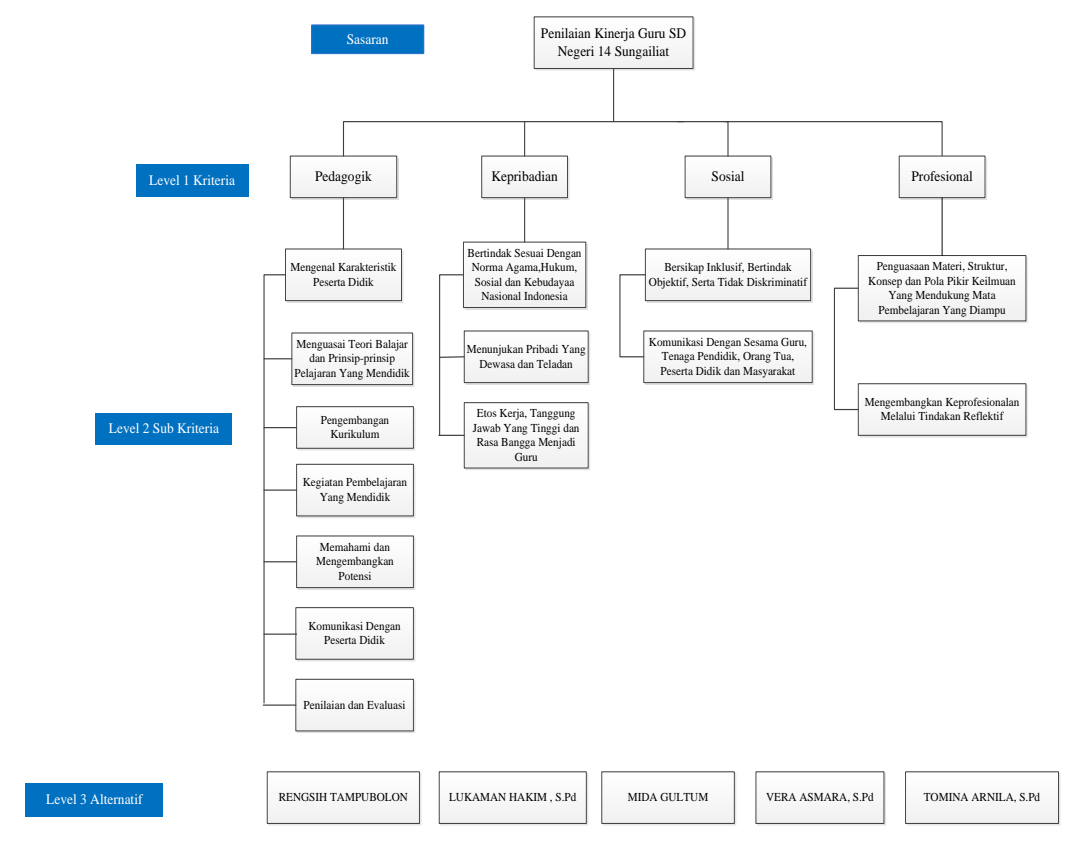

Gambar 3. Struktur Hirarki Analitik

Responden yang terlibat dalam penelitian ini adalah 4 orang yang terdiri dari kepala sekolah dan tim penilai yang terdiri dari wakil kepala sekolah, dua orang perwakilan guru, dan perwakilan komite. Semua responden yang terlibat dalam penelitian ini adalah pihak - pihak yang mengetahui proses pembelajaran dan mengetahui poin poin penilaian kinerja guru.

Hasil pengolahan data responden dilakukan dengan membandingkan tiap kriteria dalam hirarki dan perbandingan berpasangan dihitung dengan konsep perkalian matriks seperti yang tampak pada tabel - tabel berikut. Masing - masing tabel menunjukkan hasil perhitungan untuk tiap kriteria dengan level berbeda.

\subsection{Perhitungan Matriks Perbandingan Berpasangan}

Hasil perhitungan matriks perbandingan berpasangan yang ditampilkan pada beberapa tabel berikut ini adalah hasil perhitung sampel untuk satu responden saja. Tabel 1 adalah hasil perhitungan perbandingan berpasangan untuk kriteria level 1 yaitu Pedagogik Kepribadian, Sosial, dan Profesional.

Tabel 2. Matriks Perbandingan Berpasangan Kriteria Level 1

\begin{tabular}{lcccc}
\hline Komponen & Pedagogik & Kepribadian & Sosial & Profesional \\
\hline Pedagogik & 1 & 1 & 2 & 3 \\
Kepribadian & 1 & 1 & 2 & 1 \\
Sosial & 0,5 & 0,333 & 1 & 3 \\
Profesional & 0,5 & 1 & 0,333 & 1 \\
Jumlah & $\mathbf{3}$ & $\mathbf{3 , 3 3 3}$ & $\mathbf{5 , 3 3 3}$ & $\mathbf{8}$ \\
\hline
\end{tabular}

Pada tabel 2 terlihat bahwa kriteria Profesional adalah kriteria dengan bobot terbesar yaitu 8, kriteria terbesar kedua adalah Sosial sebesar 5,333, kriteria terbesar ketiga Kepribadian sebesar 3,333, dan kriteria terakhir adalah Pedagogik sebesar 3.

Berikutnya adalah tabel 3 yang menunjukkan matriks perbandingan level 2 sub kriteria Pedagogik.

System Model For Web-Based Teacher Performance Assessment.. (Hilyah Magdalena) 
Tabel 3. Matriks Perbandingan Berpasangan Kriteria Pedagogik

\begin{tabular}{lccccccc}
\hline Kriteria & $\boldsymbol{A}$ & $\boldsymbol{B}$ & $\boldsymbol{C}$ & $\boldsymbol{D}$ & $\boldsymbol{E}$ & $\boldsymbol{F}$ & $\boldsymbol{G}$ \\
\hline$A$ & 1 & 3 & 4 & 3 & 2 & 1 & 1 \\
$B$ & 0,33 & 1 & 2 & 4 & 3 & 3 & 2 \\
$C$ & 0,25 & 0,333 & 1 & 1 & 1 & 2 & 3 \\
$D$ & 0,5 & 1 & 1 & 1 & 4 & 4 & 5 \\
$E$ & 0,5 & 0,25 & 0,33 & 0,333 & 1 & 3 & 2 \\
$F$ & 0,5 & 1 & 1 & 0,5 & 0,33 & 1 & 1 \\
$G$ & 1 & 0,25 & 0,25 & 0,2 & 0,33 & 0,5 & 1 \\
Jumlah & 4,08 & 6,83 & 9,58 & 10,033 & 11,666 & 14,5 & 15 \\
\hline
\end{tabular}

Ket :
A. Mengenal Karakteristik Peserta Didik
B. Menguasai Teori Belajar dan Prinsip-Prinsip Pelajaran Yang Mendidik
C. Pengembangan Kurikulum
D. Kegiatan Pembelajaran Yang Mendidik
E. Pengembangan Potensi Peserta Didik
F. Komunikasi Dengan Peserta Didik
G. Penilaian dan Evaluasi

Pada tabel 3 terlihat bahwa sub kriteria Pedagogik yang paling tinggi bobotnya adalah Peniliaian dan Evaluasi dengan bobot 15. Selanjutnya adalah tabel 4 yang menunjukkan sub kriteria dari kriteria Kepribadian

Tabel 4. Matriks Perbandingan Berpasangan Kriteria Kepribadian

\begin{tabular}{cccc}
\hline Komponen & $\boldsymbol{A}$ & $\boldsymbol{B}$ & $\boldsymbol{C}$ \\
\hline$A$ & 1 & 3 & 4 \\
$B$ & 0,333 & 1 & 5 \\
C & 0,25 & 0,2 & 1 \\
Jumlah & 1,583 & 4,2 & 10 \\
\hline
\end{tabular}

Ket :

A. Bertindak Sesuai Dengan Norma Agama, Hukum, Sosial dan Kebudayaan Nasional Indonesia.

B. Menunjukan Pribadi Yang Dewasa dan Teladan

C. Etos Kerja, Tanggung Jawab Tinggi Rasa Bangga Menjadi Guru

Pada tabel 4 terlihat bahwa sub kriteria dari Kepribadian yang paling tinggi bobotnya adalah Etos Kerja, Tanggung Jawab Tinggi Rasa Bangga menjadi Guru dengan nilai 10. Berikutnya adalah tabel 5 yang menunjukkan hasil dari perhitungan perbandingan berpasangan untuk sub kriteria Sosial

Tabel 5. Matriks Perbandingan Berpasangan Kriteria Sosial

\begin{tabular}{ccc}
\hline Komponen & $\boldsymbol{A}$ & $\boldsymbol{B}$ \\
\hline$A$ & 1 & 3 \\
$B$ & 0,333 & 1
\end{tabular}

Jumlah $1,333 \quad 4$

TRANSFORMATIKA Vol. 17, No. 1, July 2019 : 67 - 77 
Ket :

A. Bersikap Inklusif, Bertindak Objektif, Serta Tidak Diskriminatif

B. Komunikasi Dengan Sesama Guru, Tenaga Pendidik, Orangtua, Peserta Didik dan Masyarakat

Pada tabel 5 terlihat bahwa sub kriteria Komunikasi dengan sesama guru, tenaga pendidik, orangtua, peserta didik dan masyarakat adalah sub kriteria sosial yang tertinggi dengan bobot 4 . Berikutnya adalah tabel 6 yang menunjukkan hasil perhitungan perbandingan berpasangan untuk sub kriteria Profesional.

Tabel 6. Matriks Perbandingan Berpasangan Kriteria Profesional

\begin{tabular}{lcc}
\hline Komponen & $\boldsymbol{A}$ & $\boldsymbol{B}$ \\
\hline$A$ & 1 & 3 \\
$B$ & 0,333 & 1 \\
Jumlah & 1,333 & 4 \\
\hline
\end{tabular}

Ket :

A. Penguasaan Materi, Struktur, Konsep dan Pola Pikir Keilmuan Yang Mendukung Mata Pelajaran yang diampu

B. Mengembangkan Keprofesionalan Melalui Tindakan Reflektif

\subsection{Hasil Pengolahan Data Responden Gabungan (Combined)}

Pada tabel 6 sub kriteria Profesional tertinggi denga bobot 4 adalah mengembangkan keprofesionalan melalui tindakan reflektif. Tabel 2 sampai 6 menunjukkan matriks perbandingan berpasangan yang dihitung berdasarkan rumus AHP dan dilakukan untuk responden pertama. Penelitian ini melibatkan empat orang responden yang masing - masing responden mempunyai hasil perhitungan terpisah. Setelah semua responden mempunyai hasil perhitungan, tahap selanjutnya adalah menggabungkan nilai semua responden untuk mendapatkan nilai gabungan atau nilai combined yang merupakan hasil akhir. Untuk membantu mempermudah perhitungan gabungan maka penelitian ini menggunakan alat bantu berupa aplikasi Expert Choice 11. Hasil pengolahan data gabungan responden dengan Expert Choice disajikan dalam bentuk grafik yang lebih mudah untuk dibaca.

Gambar 4 berikut ini adalah gambar Stuktur Pohon untuk Kriteria Level 1 pada Penilaian Kinerja Guru SDN 14 Sungailiat.

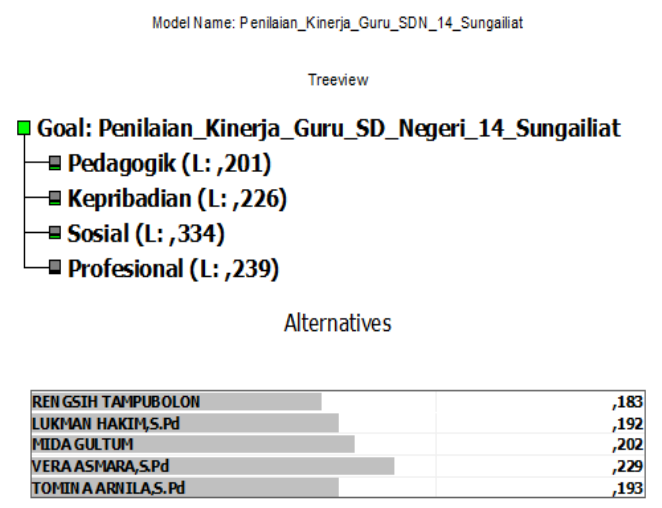

Gambar 4. Tampilan Pohon Hasil Combined Kriteria Level 1

System Model For Web-Based Teacher Performance Assessment.. (Hilyah Magdalena) 
Gambar 4 menunjukkan kriteria level 1 yang paling tinggi nilainya adalah sosial dengan bobot $33,4 \%$ dan alternatif yang tertinggi bobotnya adalah Vera Asmara S.Pd., dengan 22,9\%. Selanjutnya adalah gambar 5 yang merupakan stuktur pohon untuk sub kriteria yang berada di bawah kriteria Pedagogik.

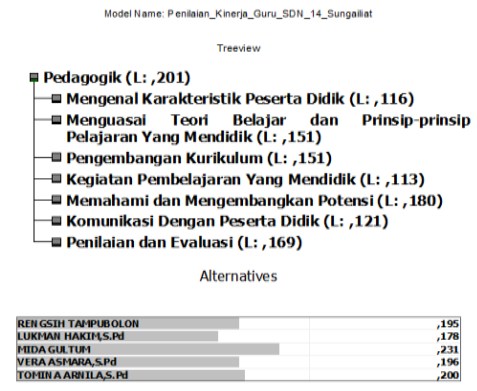

Gambar 5. Tampilan Pohon Hasil Combined Sub Kriteria Pedagogik

Gambar 5 menunjukkan sub kriteria pedagogik yang paling tinggi nilainya adalah sub kriteria Memahami dan Mengembangkan Potensi dengan bobot sebesar 18\% dengan alternatif tertinggi adalah Mida Gultum dengan bobot mencapai 19,6\%. Gambar selanjutnya adalah gambar 6 yang menunjukkan struktur pohon untuk sub kriteria dari Kepribadian.

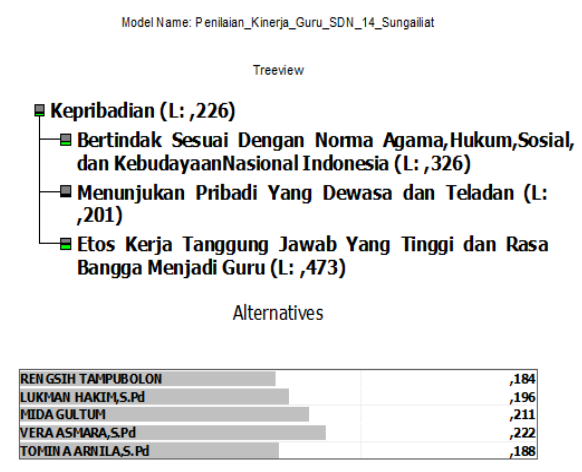

Gambar 6. Tampilan Pohon Hasil Combined Sub Kriteria Kepribadian

Gambar 6 menampilkan sub kriteria dari Kepribadian adalah Etos Kerja Tanggung Jawab Yang Tinggi dan Rasa Bangga menjadi Guru dengan bobot 47,3\% dan alternatif yang terpilih adalah Vera Asmara dengan bobot 22,2\%. Gambar 7 adalah struktur pohon untuk sub kriteria Sosial.

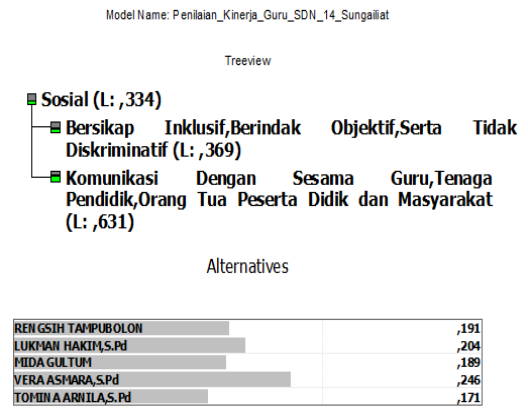

Gambar 7. Tampilan Pohon Hasil Combined Sub Kriteria Sosial

TRANSFORMATIKA Vol. 17, No. 1, July 2019: $67-77$ 
Pada gambar 7, sub kriteria sosial yang paling tinggi bobotnya adalah komunikasi dengan sesama guru, tenaga pendidik, orang tua peserta didik dan masyarakat dengan bobot $63,1 \%$ dan alternatif tertinggi adalah Vera Asmara, S.Pd sebanyak 24,6\%. Gambar 8 berikut ini adalah struktur pohon untuk sub kriteria untuk Profesional.

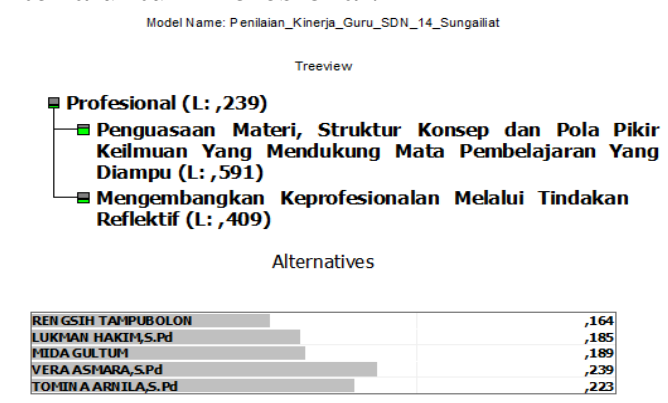

Gambar 8. Tampilan Pohon Hasil Combined Sub Kriteria Profesional

Pada Gambar 8 sub kriteria Profesional dengan bobot tertinggi adalah penguasaan materi, struktur konsep dan pola pikir keilmuan yang mendukung mata pembelajaran yang diampu sebesar 59,1\%, dan alternatif yang tertinggi adalah Vera Asmara, S.Pd sebesar 23,9\%. Gambar 9 adalah hasil alternatif yang terpilih dengan bobot tertinggi.

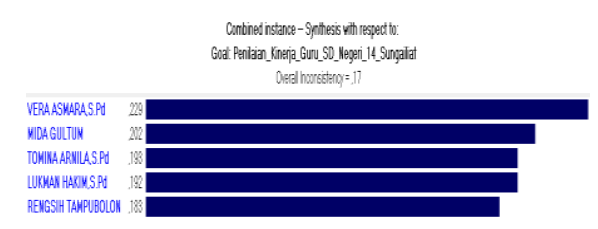

Gambar 9. Synthesis with respect to Goal

Pada Gambar 9 adalah urutan yang menunjukkan alternatif yang paling tinggi dari Vera Asmara, S.Pd dengan bobot 22,9\%, kedua adalah Mida Gultum sebesar 20,2\%, ketiga Tomina Armila, S.Pd. sebesar 19,3\%, Lukman Hakim S,Pd., sebesar 19,2\%., dan terakhir adalah Rengsih Tampubolon dengan bobot sebesar 18,3\%.

\subsection{Desain Sistem Berbasis Web}

Setelah struktur pengambilan keputusan didesain dengan Analytical Hierarchy Process, tahap selanjutnya adalah mendesain sistem berbasis web agar sistem pengambilan keputusan dapat dilakukan lebih mudah, akurat, dan fleksibel. Desain sistem berbasis web dilakukan dengan metode Object Oriented Analysis and Design (OOAD) dan beberapa diagram Unified Modelling Language (UML). Pada use case digram pendataan, staff TU bertanggungjawab untuk menginput data kriteria utama. Setelah itu Staff TU juga menginput data sub kriteria Pedagogik, Kepribadian, Sosial, Profesional. Setelah data kriteria level 1 dan level 2 selesai, selanjutnya adalah menginput data alternatif atau kriteria level 3. Proses input pendataan ini sesuai dengan hirarki analitik yang sudah terbentuk dengan metode Analytical Hierarchy Process (AHP). 
Gambar 10. Use Case Diagram

Pada gambar 10 adalah use case diagram pertama untuk desain sistem berbasis web ini. Pada tahap pendataan, Staff TU mempersiapkan semua data yang diperlukan untuk proses pengambilan keputusan berbasis web ini. Selanjutnya adalah desain antar muka sistem dengan actor. Desain antar muka adalah tampilan form atau layar yang dapat digunakan actor yang login dalam sistem berbasis web.

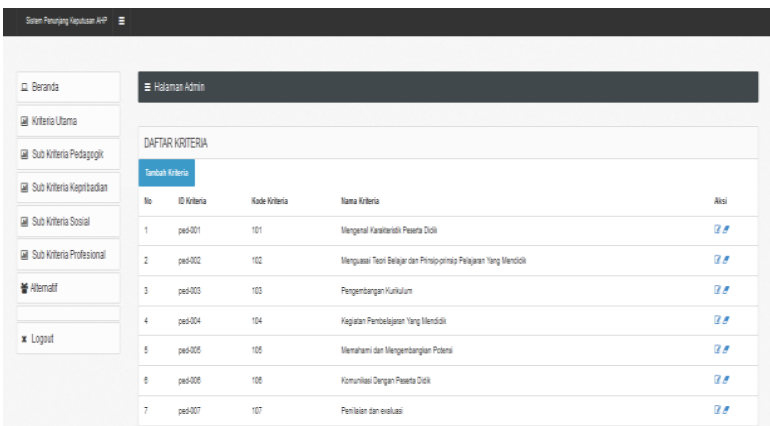

Gambar 11. Desain Form Entry Data Sub Kriteria Level 1

Desain form entry data sub kriteria level satu disusun berurutan sesuai dengan hirarki AHP dan disisi kanan disiapkan tools untuk pilihan aksi yang dapat dilakukan tim penilai pada saat menginput nilai perbandingan berpasangan.

\section{Kesimpulan}

Berdasarkan hasil desain sistem pendukung keputusan dengan metode AHP dan desain sistem berbasis web dengan OOAD, maka sistem pendukung keputusan berbasis web untuk menilai kinerja guru di SDN 14 Sungailiat dapat lebih akurat, fleksibel, paperless, dan adil. Hasil penilaian adalah hasil gabungan tim penilai dan saat penilaian dapat dilakukan kapan saja dalam rentang waktu tertentu karena masing - masing tim penilai dapat login ke sistem dengan akunnya masing - masing. Hasil penilaian juga dapat lebih akurat dan meminimalkan penggunaan kertas, karena semua nilai responden tidak perlu lagi di tulis dikertas namun dapat diinput langsung ke sistem pendukung keputusan berbasis web.

\section{References}

[1] Peraturan Pemerintah Republik Indonesia Nomor 19 Tahun 2017 Tentang Perubahan Atas Peraturan Pemerintah Nomor 74 Tahun 2008 Tentang Guru.

[2] Undang-Undang Republik Indonesia Nomor 14 Tahun 2005 Tentang Guru Dan Dosen

[3] Penilaian Kinerja Guru, Direktorat Tenaga Kependidikan Direktorat Jenderal Peningkatan Mutu Pendidik Dan Tenaga Kependidikan Departemen Pendidikan Nasional 2008

TRANSFORMATIKA Vol. 17, No. 1, July 2019: $67-77$ 
[4] A. Paramita, F. A. Mustika, N. Farkhatin, "Aplikasi Sistem Pendukung Keputusan Guru Terbaik Berdasarkan Kinerja dengan Metode Analytical Hierarchy Process (AHP)", TEKNOSI, Vol. 03, No. 01, pp. $9-18$, April 2017

[5] T. Mufizar, Susanto, N. Nurjayanti, "Sistem Pendukung Keputusan Penilaian Kinerja Guru di SDN Mohammad Toha menggunakan Analytical Hierarchy Process (AHP)", in Konferensi Nasional Sistem \& Informatika 2015, pp. 581 - 586

[6] Sopiah, E. K. Putra, A. I. Hadiana, "Sistem Pendukung Keputusan Rekomendasi Guru Tetap Berdasarkan Data Guru Honorer Berprestasi Menggunakan Metode Analytic Hierarchy Process (AHP) dan Simple Additive Weighting (SAW)", in Seminar Nasional Teknologi Informasi dan Multimedia 2017, pp.79-84

[7] Fahrizal, "Sistem Pendukung Keputusan Penilaian Kinerja Guru Berdasarkan Hasil Evaluasi Umpan Balik Dari Beban Kerja Menggunakan Metode Analytical Hierarchy Process (AHP) (Studi Kasus : SD LPI At-Taufiq)", JURNAL LENTERA ICT Vol.3 No.1, pp. 19 - 27, Mei 2016

[8] O. S. Vaidya, S. Kumar," Analytic hierarchy process: An overview of applications", European Journal of Operational Research 169, pp.1-29, 2006

[9] Thomas L=-. Saaty, "How to make a decision: The Analytic Hierarchy Process", European Journal of Operational Research 48, pp 9-26, 1990

[10] Thomas L. Saaty, Luis G. Vargas, Models, Methods, Concepts \& Applications of the Analytic Hierarchy Process Second Edition, International Series in Operations Research \& Management Science Volume 175, Springer New York Heidelberg Dordrecht London, 2012

[11] Thomas L. Saaty, "Some Mathematical Concepts Of The Analytic Hierarchy Process" Behaviormetrika No.29, pp. 1-9, 1991

[12] Thomas L. Saaty, "Decision Making with the Analytic Hierarchy Process", Int. J. Services Sciences, Vol. 1, No. 1, pp. 83 - 98, 2008.

[13] Ernest Forman, Kirti Peniwati, “Aggregating individual judgments and priorities with the Analytic Hierarchy Process", European Journal Of Operational Research

[14] Thomas L. Saaty · Mujgan Sa gır Özdemir, "How Many Judges Should There Be in a Group ?", ( Springer-Verlag Berlin Heidelberg 2015. 